УДК 577.115.3:591.13

\author{
В. В. Цюпко
}

Інститут тваринництва УААН

\title{
СКЛАД МОЛОЧНОГО ЖИРУ КОРІВ У РІЗНІ СТРОКИ ПІСЛЯ ОТЕЛЕННЯ
}

\begin{abstract}
Проаналізовано експериментальні дані щодо вмісту основних жирних кислот у молоці корів залежно від стадії лактації. Показано, що стадія лактації більше впливає на вміст біологічно цінних ненасичених міристолеїнової, лінолевої та ліноленової кислот. Інша частина жирних кислот має порівняно сталу конфігурацію.
\end{abstract}

В. В. Цюпко

Институт животноводства УААН

\section{СОСТАВ МОЛОЧНОГО ЖИРА КОРОВ В РАЗНЫЕ СРОКИ ПОСЛЕ ОТЕЛА}

Проанализирован жирнокислотный состав молока коров в зависимости от стадии лактации. Показано, что влиянию стадии лактации более подвержены биологически ценные ненасыщенные жирные кислоты: миристолеиновая, линолевая и линоленовая. Остальная часть кислот в разные сроки после отела имеет относительно постоянную конфигурацию.

\section{V. Tsyupko \\ Institute of Animal Husbandry, UAAS \\ COMPOSITION OF COWS' BUTTERFAT IN DIFFERENT TERMS AFTER CALVING}

Influence of the lactation stage on cow milk's fatty acids composition has been studied. The lactation stage has influence on the content of biologically valuable unsaturated myristoleic, linoleic and linolenic acids. Other fatty acids are relatively stable.

\section{Вступ}

У сучасних умовах все підвищуються вимоги не тільки до рівня продуктивності молочного стада, а і до вмісту в молоці основних компонентів (жиру, білка та лактози). Передусім це пов'язано з направленістю використання молока як сировини. При виготовленні вершків або вершкового масла необхідне молоко з високим умістом жиру. Для виготовлення сиру бажаним є високий вміст білка, а для виготовлення кисломолочних продуктів необхідний високий рівень лактози, що забезпечує в результаті процесу бродіння достатній рівень молочної кислоти в кінцевому продукті.

Крім даних щодо складу та співвідношення жиру, білка та лактози молока, все більша увага приділяється жирнокислотному складу молочного жиру, особливо вмісту життєво необхідних, есенціальних жирних кислот, що визначають дієтичні властивості молока. Основна маса ліпідів молока представлена тригліцеридами жирних кислот.

(C) В. В. Цюпко, 2010 
Актуальність вивчення складу молочного жиру пов'язана, головним чином, із суттєвим впливом вмісту та співвідношення жирних кислот на технологічні якості молока як сировини та його дієтичні властивості. У наш час проводиться багато дискусій щодо впливу жирнокислотного складу на стан серцево-судинної системи та захворювань серця, на виникнення та хід онкологічних захворювань людини. Встановлено, що поліненасичені жирні кислоти (ПНЖК) попереджують розвиток серцево-судинних розладів шляхом впливу на мембрани клітин [6]. 3 іншого боку, деякі ненасичені жирні кислоти попереджують розвиток діабету. У зв'язку з актуальністю даної проблеми ведуться пошуки шляхів отримання бажаного жирнокислотного складу молока шляхом корекції раціонів [2; 3; 5]. Встановлено, що кон'югована лінолева кислота гальмує канцерогенез [4]. Також велике значення має з'ясування взаємозв'язку між окремими компонентами молока, що дозволяє оцінювати направленість і взаємозалежність процесів синтезу [1].

У молочному жирі виявлені жирні кислоти, що належать до різноманітних гомологічних рядів: насичені та ненасичені (різною мірою). Більшість із них представлена в малих кількостях, і лише концентрація 15-16 кислот перевищує 0,6-1,0 \% за масою. У цілому молочний жир за різноманіттям жирних кислот і тригліцеридів значно переважає всі відомі жири тваринного походження та рослинні олії.

На жирнокислотний склад молока впливають різні чинники, такі як рівень годівлі, структура та склад раціону, метаболізм шлунково-кишкового тракту тварин тощо. Слід візначити, що далеко не все відомо про вміст і співвідношення окремих жирних кислот молока корів, їх зв'язок з основними компонентами молока, вплив на його дієтичні якості. Тому мета цього дослідження - визначити жирнокислотний склад молока залежно від стадії лактації.

\section{Матеріал і методи досліджень}

Дослідження проводили на коровах ДП «Кутузівка» Харківського району Харківської області. Відібрано тварин із середнім добовим надоєм 15-28 кг молока. Порода корів - українська чорно-ряба. Досліди проведено при зимовому типі годівлі тварин. Молоко відбирали під час контрольного доїння. Аналізи були проведені в лабораторії екологічного моніторингу та якості продуктів тваринного походження Інституту тваринництва УААН. Вміст жиру, білка та лактози визначали на приладі «Бентлі», а жирнокислотний склад - методом газорідинної хроматографії на хроматографі «Хром-5» з полум’яно-іонізаційним детектором.

\section{Результати та їх обговорення}

Відібране молоко поділили на три групи (залежно від стадії лактації тварин). За даними, отриманими хроматографічно, визначали та розраховували співвідношення жирних кислот: каприлової $\left(\mathrm{C}_{8: 0}\right)$, капринової $\left(\mathrm{C}_{10: 0}\right)$, капринолеїнової $\left(\mathrm{C}_{10: 1}\right)$, лауринової $\left(\mathrm{C}_{12: 0}\right)$, лауролеїнової $\left(\mathrm{C}_{12: 1}\right)$, міристинової $\left(\mathrm{C}_{14: 0}\right)$, міристолеїнової $\left(\mathrm{C}_{14: 1}\right)$, пальмитинової $\left(\mathrm{C}_{16: 0}\right)$, пальмитолеїнової $\left(\mathrm{C}_{16: 1}\right)$, стеаринової $\left(\mathrm{C}_{18: 0}\right)$, олеїнової $\left(\mathrm{C}_{18: 1}\right)$, лінолевої $\left(\mathrm{C}_{18: 2}\right)$, ліноленової $\left(\mathrm{C}_{18: 3}\right)$. У таблиці 1 наведено вміст жирних кислот, відсоток жиру, білка, лактози та сухої речовини молока корів залежно від стадії лактації.

До першої групи віднесено 5 зразків молока корів, що перебували на першій стадії лактації (у середньому 84 доби), до другої - 37 зразків корів другої стадії лактації (у середньому 122 доби), до третьої групи - 19 зразків молока корів третьої стадії лактації (у середньому 170 діб). Показники вмісту жиру, білка, лактози, сирої речовини та надою за одне доїння за групами не мають достовірних відмінностей. 
Вміст жирних кислот молока корів залежно від стадії лактації

\begin{tabular}{|l|c|c|c|}
\hline \multicolumn{1}{|c|}{ Показники } & I група $(n=5)$ & II група $(n=37)$ & III група $(n=19)$ \\
\hline Днів після отелення & $84 \pm 4,53$ & $122 \pm 3,00$ & $170 \pm 9,81$ \\
\hline Середньодобовий надій, кг & $18,10 \pm 1,63$ & $16,5 \pm 0,94$ & $17,5 \pm 1,03$ \\
\hline Вміст жиру, \% & $3,96 \pm 0,15$ & $4,41 \pm 0,37$ & $3,41 \pm 0,28$ \\
\hline Вміст білка, \% & $3,35 \pm 0,20$ & $3,31 \pm 0,11$ & $3,31 \pm 0,06$ \\
\hline Вміст лактози, \% & $4,86 \pm 0,18$ & $4,80 \pm 0,04$ & $4,89 \pm 0,06$ \\
\hline \multicolumn{4}{|c|}{ Вміст жирних кислот } \\
\hline $\mathrm{C}_{8: 0}$ & $0,82 \pm 0,06$ & $2,46 \pm 0,58^{* *}$ & $1,09 \pm 0,57$ \\
\hline $\mathrm{C}_{10: 0}$ & $4,53 \pm 0,90$ & $4,88 \pm 0,48$ & $5,49 \pm 0,82$ \\
\hline $\mathrm{C}_{10: 1}$ & $0,04 \pm 0,03$ & $0,52 \pm 0,16$ & не ідентифіковано \\
\hline $\mathrm{C}_{12: 0}$ & $4,81 \pm 0,80$ & $4,13 \pm 0,43$ & $3,95 \pm 0,53$ \\
\hline $\mathrm{C}_{12: 1}$ & не ідентифіковано & $1,33 \pm 0,41$ & $2,43 \pm 0,90$ \\
\hline $\mathrm{C}_{14: 0}$ & $9,78 \pm 0,92$ & $10,72 \pm 0,76$ & $9,19 \pm 1,11$ \\
\hline $\mathrm{C}_{14: 1}$ & $1,22 \pm 0,33$ & $4,50 \pm 0,78^{*}$ & $5,94 \pm 1,20^{*}$ \\
\hline $\mathrm{C}_{16: 0}$ & $36,81 \pm 2,85$ & $32,96 \pm 2,01$ & $31,67 \pm 3,50$ \\
\hline $\mathrm{C}_{16: 1}$ & не ідентифіковано & не ідентифіковано & $0,73 \pm 0,49$ \\
\hline $\mathrm{C}_{18: 0}$ & $11,37 \pm 1,42$ & $10,39 \pm 1,44$ & $12,87 \pm 3,18$ \\
\hline $\mathrm{C}_{18: 1}$ & $26,86 \pm 0,99$ & $22,72 \pm 1,48$ & $20,31 \pm 2,60$ \\
\hline $\mathrm{C}_{18: 2}$ & $3,11 \pm 0,57$ & $5,98 \pm 1,24 *$ & $6,04 \pm 1,31^{* *}$ \\
\hline $\mathrm{C}_{18: 3}$ & $0,99 \pm 0,45$ & $1,88 \pm 0,33^{* *}$ & $1,87 \pm 0,51^{* *}$ \\
\hline
\end{tabular}

Примітки: * $-p<0,05$ - порівняно з першою групою, ** $-p<0,01$.

Отримані дані показують, що існує достовірна різниця за вмістом деяких жирних кислот залежно від стадії лактації. Вміст $\mathrm{C}_{8: 0}$ суттєво вищий у молоці корів II та III груп порівняно 3 I, а саме, у II - на $66 \%(p<0,01)$, у III - на $25 \%$ (різниця на рівні тенденції). Суттєва різниця встановлена за концентрацією міристолеїнової кислоти $\left(\mathrm{C}_{14: 1}\right)$. Вона нижча на 73 \% у першу стадію лактації порівняно з другою, та на 80 \% порівняно 3 третьою стадією $(p<0,001)$.

Для молочного жиру властивий досить високий (порівняно $з$ іншими жирами) вміст поліненасичених довголанцюгових жирних кислот (лінолевої $\mathrm{C}_{18: 2}$ та ліноленової $\mathrm{C}_{18: 3}$ ), які не синтезуються в організмі людини та тварини. У таблиці показано, що вміст лінолевої кислоти $\mathrm{C}_{18: 2}$ У другу стадію лактації вищий на $48 \%(p<0,01)$, ніж у першу; у третю стадію лактації - на $49 \%(p<0,05)$ вищий порівняно з першою. Таку ж закономірність виявлено стосовно вмісту ліноленової кислоти $\mathrm{C}_{18: 3}$ : як у другу, так і в третю стадії іï концентрація була на $47 \%(p<0,05)$ вищою, ніж у першу.

Незалежно від стадії лактації основна частка жирних кислот (до 80 \%) представлена чотирма кислотами: $\mathrm{C}_{14: 0}-10, \mathrm{C}_{16: 0}-34, \mathrm{C}_{18: 0}-11, \mathrm{C}_{18: 1}-24 \%$.

Кореляційним аналізом установлено позитивний зв'язок жирної кислоти $\mathrm{C}_{14: 0} 3$ $\mathrm{C}_{16: 0}(r=0,46)$ i $_{18: 0}(r=0,48)$, і негативний із $\mathrm{C}_{18: 1}(r=-0,65)$. Між кислотами $\mathrm{C}_{16: 0}$ i $_{18: 0}$ зв'язок негативний $(r=-0,67)$. Кореляційний зв'язок жирних кислот із надоєм недостовірний на даному інтервалі молочної продуктивності.

Вивчення кореляційних зв'язків між основними компонентами молока корів ДП «Кутузівка» показало, що між надоєм і вмістом жиру значимий негативний зв' язок $(r=-0,29)$. У дослідах на коровах фізіологічного двору встановлено існування позитивного зв'язку між вмістом жиру та білка в молоці $(r=0,51)$.

Таким чином, у дослідах на коровах фізіологічного двору та ДП «Кутузівка» встановлено, що незалежно від стадії лактації основна частка жирних кислот (до 80 \%) представлена чотирма кислотами: $\mathrm{C}_{14: 0}-9-10, \mathrm{C}_{16: 0}-34-39, \mathrm{C}_{18: 0}-8-11, \mathrm{C}_{18: 1}-24-26 \%$. 
Доведено, що вміст лінолевої та ліноленової кислот, які визначають дієтичні властивості молока корів, вищий після 100 діб лактації.

\section{Висновки}

1. Кількість лінолевої кислоти $\mathrm{C}_{18: 2}$ на $48 \%$ ( $\left.p<0,01\right)$ вища в другу стадію, та на $49 \%(p<0,05)$ - у третю стадію лактації порівняно $з$ першою.

2. Кількість ліноленової кислоти $\mathrm{C}_{18: 3}$ на $47 \%(p<0,05)$ вища в другу та третю стадію лактації порівняно з першою.

3. Порівняно з першою стадією лактації у складі жирних кислот відмічено достовірну різницю за вмістом каприлової кислоти $\mathrm{C}_{8: 0}$ (він вищий у другу стадію на $66 \%$, $p<0,01)$. На рівні тенденції у третій стадії ії концентрація була вищою на $25 \%$.

4. Суттєва різниця встановлена за концентрацією міристолеїнової кислоти $\mathrm{C}_{14: 1}$. Вона на 73 \% нижча у першу стадію лактації порівняно з другою, та на 80 \% порівняно 3 третьою стадією.

5. Незалежно від стадії лактації основна частка жирних кислот (до 80 \%) представлена чотирма кислотами: міристиновою $\mathrm{C}_{14: 0}-9-10 \%$, пальмитиновою $\mathrm{C}_{16: 0}-34-39 \%$, стеариновою $\mathrm{C}_{18: 0}-8-11 \%$, олеїновою $\mathrm{C}_{18: 1}-24-26 \%$.

\section{Бібліографічні посилання}

1. Вудмаска I. В. Метаболізм у рубці та його вплив на жирнокислотний склад ліпідів молока корів за різного вуглеводного і ліпідного складу раціону. Автореф. дис. ... д-ра с.-г. наук. Львів : УААН, Інститут біології тварин, 2008. - 38 с.

2. Мартин М. Т. Молочна продуктивність і жирнокислотний склад ліпідів молока за використання у раціонах корів рослинно-олійних добавок / М. Т. Мартин, С. О. Вовк, С. Я. Павлович // Корми і кормовиробництво. - 2004. - Вип. 54. - С. 191-195.

3. Мартин М. Т. Жирнокислотний склад ліпідів плазми крові і молока при використанні у раціонах корів жирових добавок рослинного походження. Автореф. дис. ... канд. с.-г. наук. - Львів : УААН, Інститут біології тварин, 2006. - 18 с.

4. Belury M. A. Dietary conjugated linoleic acid in health: physiological effects and mechanisms of action // Annu. Rev. Nutr. - 2002. - Vol. 22. - P. 505-531.

5. Composition of fatty acid in cow's milk fat produced in the lowlands, mountaints and highlands of Switzerland using high-resolution gas chromatography / M. Collomb, U. Bitikofer, R. Sieber et al. // International Dairy Journal. - 2002. - Vol. 12, N 8. - P. 649-659.

6. Okuyama H. High $n-6$ to $n-3$ ratio of dietary fatty acids rather than serum cholesterol as a major risk factor for coronary heart disease // European Journal of Lipid Science and Technology. - 2001. Vol. 103. - P. 418-422. 